${ }^{4}$ Packe GE, Innes JA. Protective effect of BCG vaccination in infant Asians: a case-control study. Arch Dis Child 1988;63: 277-81.

G E PACKe and J A InNeS Birmingham Chest Clinic, Birmingham

\section{Tubular dysfunction and microalbuminuria in insulin dependent diabetes}

Sir,

In a recent paper by Walton et al investigating tubular function in diabetics, urinary $\alpha-1$-microglobulin excretion was found to be significantly higher in diabetic children compared with controls. ${ }^{1}$ Using an enzyme immunoassay (Imzyne $\alpha_{1}-\mathrm{M}$, Fujirebio Inc) we obtained similar results. ${ }^{2}$

In 62 type 1 diabetics ( 38 girls), aged 3 to 21 years, with duration of disease from one week to 13 years, urinary $\alpha-1-$ microglobulin excretion was evaluated prospectively every three months for one year; 54 healthy subjects (32 girls), aged 4 to 21 years served as controls. Diabetics were divided into three groups according to their duration of disease (group A: less than five years; group B: five to 10 years; group C: more than $\mathbf{1 0}$ years); during the study 28 poorly controlled children (with stable glycated haemoglobin $\left(\mathrm{HbA}_{1 \mathrm{c}}\right)$ concentration $>10 \%$ ) improved their metabolic control and after 12 months $\mathrm{HbA}_{1 \mathrm{c}}$ concentrations were less than $8 \%$. In diabetics urinary excretion of $\alpha-1$-microglobulin was significantly higher than in controls, particularly in group $\mathrm{C}$ patients. In agreement with $\mathrm{Dr}$

Table Urinary $\alpha$-1-microglobulin excretion ( $\mathrm{mg} / \mathrm{mmol}$ creatinine) in 28 poorly controlled diabetic children and in 54 normal children

\begin{tabular}{|c|c|c|}
\hline & $\begin{array}{l}\text { During poor } \\
\text { glycaemic control } \\
\text { (stable } H b A_{\text {lc }} \\
>10 \%)\end{array}$ & $\begin{array}{l}\text { After } 12 \text { months } \\
\text { of improved } \\
\text { metabolic control } \\
\left(H b A_{l c}<8 \%\right)\end{array}$ \\
\hline \multicolumn{3}{|c|}{$\begin{array}{l}\text { Diabetic children: } \\
\text { Group A }(n=9)\end{array}$} \\
\hline Median & $0.54^{*}$ & 0.27 \\
\hline Range & $0 \cdot 21-1 \cdot 64$ & $0 \cdot 11-0.94$ \\
\hline \multicolumn{3}{|c|}{ Group B $(n=10)$} \\
\hline Median & $0 \cdot 62^{*}$ & 0.29 \\
\hline Range & $0 \cdot 18-1 \cdot 78$ & $0 \cdot 16-0.96$ \\
\hline \multicolumn{3}{|c|}{ Group $C(n=9)$} \\
\hline Median & $0 \cdot 75^{*}$ & $0.66^{*}$ \\
\hline Range & $0 \cdot 28-2.07$ & $0.22-1.98$ \\
\hline \multicolumn{3}{|c|}{ Normal children } \\
\hline Median & 0.25 & \\
\hline Range & $0.10-0.88$ & \\
\hline
\end{tabular}

${ }^{*} \mathrm{p}<0.001$ compared with normal children.
Walton's study, a significant correlation was found between $\mathrm{HbA}_{1 \mathrm{c}}$ values and urinary $\alpha-1$-microglobulin excretion as well as between 24 hour glycosuria and urinary excretion of $\alpha$-1-microglobulin. In poorly controlled diabetics with duration of disease shorter than 10 years (group $A$ and $B$ ) urinary $\alpha-1$-microglobulin excretion returned to normal when metabolic control improved, while it remained high in children with duration of diabetes longer than 10 years (group C) (table). Albumin excretion rate was less than $15 \mu \mathrm{g} /$ minute in all diabetic children during the study.

Our data confirm that glycaemic control influences urinary excretion of $\alpha$-1-microglobulin; however, despite good metabolic control, children with long duration of diabetes and without microalbuminuria show an increased excretion of $\alpha$-1-microglobulin.

Although diabetic kidney disease is primarily a glomerulopathy, ${ }^{3}$ we believe that impaired tubular function is detectable earlier than glomerular damage.

\section{References}

1 Walton C, Bodansky HJ, Wales JK, Forbes MA, Cooper EH. Tubular dysfunction and microalbuminuria in insulin dependent diabetes. Arch Dis Child 1988;63:244-9.

${ }^{2}$ Chiarelli F, La Penna G, Anichini M, Morgese G. Urinary excretion of $\alpha$-1-microglobulin in children with type 1 (insulindependent) diabetes mellitus. Pediatr Res 1987;22:218.

${ }^{3}$ Mackintosh D, Viberti GC, Keen H. Proteinuria in diabetes. Diabetologia 1983;24:304.

F Chiarelli, G la Penna, and G Morgese University Department of Paediatrics, Ospedale Pediatrico, I 66100 Chieti, Italy

\section{Bulging fontanelles in infants without meningitis}

Sir,

We read with interest the article by Mann et al on transient intracranial hypertension of infancy. ${ }^{1}$ We submitted a similar report to this journal in 1986 that was not accepted for publication in competition with other papers coming through at that time.

Over a six year period, seven infants (see table) were admitted to the Royal Alexandra Hospital for Sick Children, Brighton, with bulging fontanelles and fever. Examination of the cerebrospinal fluid and blood cultures was normal in each case. All seven were previously healthy, but case $\mathbf{4}$ had Poland's anomaly. Cerebrospinal fluid pressure was raised in the three infants who had the investigation performed. All the infants' fontanelles had returned to normal within 72 hours. We believe all our patients were suffering from viral infections, but the relevant investigations were not complete. A history of mild head injury was obtained in case 3 . In two of our cases the bulging fontanelles returned in the presence of further infections. The mother of case 4 brought her daughter back 